\title{
Growth performance and body composition of hybrid red tilapia (Oreochromis mossambicus $\times$ O. aureus) fed with different protein levels raised in saltwater
}

\author{
Daniel Correia ${ }^{1}$, Brandon Escarcega-Miranda ${ }^{2}$, Fernando Barreto-Curiel ${ }^{2}$, José Mata-Sotres ${ }^{3}$ \\ Oscar Del Rio-Zaragoza ${ }^{2}$, María Teresa Viana ${ }^{2}$ \& Artur Nishioka Rombenso ${ }^{2,4}$ \\ ${ }^{1}$ Univerisidad Federal do Rio Grande, Rio Grande, RS, Brasil \\ ${ }^{2}$ Universidad Autónoma de Baja California, Baja California, México \\ ${ }^{3}$ CONACYT - Universidad Autónoma de Baja California, México \\ ${ }^{4}$ Commonwealth Scientific and Industrial Research Organization (CSIRO) \\ Queensland, Australia \\ Corresponding author: Artur N. Rombenso (artur.rombenso@ csiro.au)
}

\begin{abstract}
The present study evaluated the growth performance and whole-body composition of the hybrid red tilapia (Oreochromis mossambicus $\times$ O. aureus) raised in saltwater and fed three experimental diets containing different protein levels $(25.6,30.8$ and 35.6\% CP; crude protein). The hybrid red tilapia showed a high production performance across all dietary treatments: specific growth rate (SGR) $=3.12-3.51 \%$ body weight $\mathrm{d}^{-1}$; weight gain $=391-503 \%$; feed conversion ratio $(\mathrm{FCR})=0.90-1.07$; thermal growth coefficient $(\mathrm{TGC})$ $=1.50-1.67$; condition factor $(\mathrm{CF})=0.19-0.26$. Dietary protein content significantly affected feed intake; fish fed the $30.8 \% \mathrm{CP}$ diets displayed higher feed intake than those fed the $25.6 \% \mathrm{CP}$ diet. Although the protein efficiency ratio (PER) was not significantly affected by dietary treatments, fish fed $25.6 \%$ CP diet demonstrated numerically higher values than those fed the other dietary treatments (4.34 vs. 3.06-3.35). The viscerosomatic index was significantly reduced in the $25.6 \% \mathrm{CP}$ group compared to 30.8 and $35.6 \% \mathrm{CP}$ groups. Regarding the whole-body composition, dietary protein affected all parameters, except lipid content. Fish fed the $30.8 \% \mathrm{CP}$ diet exhibited significantly reduced relative protein content and elevated ash content in the whole-body in comparison to other dietary groups. The results of the present study indicated that juveniles of hybrid red tilapia accepted all dietary treatments. However, according to polynomial regression analyses based on PER and the high ash content in tilapias fed the $30.8 \% \mathrm{CP}$, it is suggested that the optimum dietary protein content for juvenile hybrid red tilapia was $25.6 \%$.
\end{abstract}

Keywords: hybrid red tilapia; protein; nutrition; whole-body composition; saltwater; aquaculture

Tilapia (Oreochromis spp.) and its hybrids have been contributing to the global growth of aquaculture. It is expected by 2030 that tilapia culture will reach 7.3 million tonnes annually, mostly based on three species $O$. niloticus, O. aureus and O. mossambicus (Msangi et al., 2013; FAO, 2016). The hybrid red tilapia is considered as the most important for commercial aquaculture. The ease adaptation to culture conditions and confinement, salinity tolerance and its attractive color that enhances the retail value (Brol et al., 2017; He et al., 2017; Nakphet et al., 2017) are among the principal reasons for its popularity. The culture in the Americas began with the introduction of the Oreochromis mossambicus species. However, the hybridization was a significant advance towards the growth in tilapia production in this continent (Watanabe et al., 2002).

Research on the hybrid red tilapia (O. mossambicus $\times O$. aureus) is still scarce with few reports on nutritional demands and requirements, and even less under the marine environment (Barreto-Curiel et al., 2015). For example, Botello-Leon et al. (2011) reported a successful partial fish meal replacement with sugar cane protein meal (14\%) in this hybrid. Regarding the dietary protein content, it has been reported a requirement between $30-40 \%$ to optimize growth at the juvenile stage (Ma et al., 2015; Liu et al.,

Corresponding editor: Crisantema Hernández 
2017). However, there is no published document on dietary protein demand with marine hybrid red tilapia. Currently, the availability of freshwater is limited, so in order to increase the sustainable tilapia culture, it is important to encourage their seawater culture.

When fish are fed protein-poor diets (i.e., the dietary protein levels are lower than the fish physiological demand) growth and production performances are impaired and depending on the circumstances their health and welfare might be affected as well. On the other hand, when fish are fed protein-rich diets, in which dietary protein content exceeds their physiological demand, growth and production performances are not optimized due to catabolic processes with a concomitant increase in ammonia excretion (Kaushik \& Seiliez, 2010; Carvalho et al., 2017).

Optimizing dietary protein is essential for a sustainable and flourishing aquaculture operation. As fish exhibits a high protein requirement, this macronutrient influences directly on the feed cost, and consequently, the operational aquaculture costs (ElSaidy \& Caber, 2005). Accordingly, the present study evaluated the performance, and whole-body composition of juvenile hybrid red tilapia fed three dietary protein levels raised in saltwater.

Dietary formulations were based on the known nutritional demands and requirements of the species (Barreto-Curiel et al., 2015). Diets were then prepared with a combination of fish meal, poultry by-product meal, soybean meal and gelatin as primary protein sources (Table 1). The experimental diets were formulated to contain three different levels of protein (25.6, $30.8,35.6 \%$ crude protein; CP) and approximately $8 \%$ of crude fat; $\mathrm{CF}$.

The experimental diets were manufactured at Laboratorio de Nutrición y Fisiología Digestiva (UABC, B.C., Mexico) according to the in-house protocols. Briefly, macronutrients were pulverized using a $0.8 \mathrm{~mm}$ mesh (Pulvex 2000, Mexico), sifted (500 $\mu \mathrm{m}$ mesh; Kemutek-Gardner K300, USA) and mixed using a vertical cutter-mixer (Robot Coupe, USA) until a homogenized meal was achieved. Micronutrients were mixed for a minute (Robot Coupe R-60, USA), and then incorporated into the bulk mixture. Beef tallow was heated prior to addition to the dough and mixed thoroughly, and then water was added until the desired texture was achieved. The dough was pelleted 2-3 mm using a commercial-grade food grinder and dried at $60^{\circ} \mathrm{C}$ until $>90 \%$ dry matter was obtained. All diets were maintained cooled at $4^{\circ} \mathrm{C}$ throughout feeding trial.

Additionally, the experimental diets were analyzed in triplicate to confirm proximate composition, according to AOAC (1995; Table 1). The dry matter content was determined by weight difference before and after drying ground samples at $60^{\circ} \mathrm{C}$ for $24 \mathrm{~h}$. Ash was determined gravimetrically from the ground sample after using the muffle furnace at $550^{\circ} \mathrm{C}$ for six hours. Crude protein was calculated by nitrogen conversion $(\% \mathrm{~N} \times 6.25)$, nitrogen content was measured by the micro-Kjeldahl method followed by distillation and titration. Crude fat was determined gravimetrically and extracted with Soxhlet method using petroleum ether as a solvent.

The study was carried out at UABC, where juvenile hybrid red tilapia (O. mossambicus $\times$ O. aureus) with an average of $4.17 \pm 0.53 \mathrm{~g}$ (mean $\pm \mathrm{SE}$, standard error) were acclimated for two weeks in $500 \mathrm{~L}$ tanks under a recirculation aquaculture system. Twelve fish per tank were stocked into nine tanks of $200 \mathrm{~L}$ with natural marine seawater under a recirculation system. Each tank consisted of an experimental unit with an individual biological filter and settler, and the water was recirculated by an air-lift pump. The aeration was kept constant in all tanks using aeration stones.

Water salinity, temperature and dissolved oxygen (YSI, PRO 20), were monitored daily. The nitrogenous components and $\mathrm{pH}$ (API test; Aquarium Pharmaceutical, Inc., Canada) were monitored three times a week. Every two days the experimental tanks were siphoned to remove feces. Fish were hand-fed daily to apparent satiation three times a day $(8: 00,12: 00$ and 16:00 h) for 52 days.

Water quality conditions were maintained within the optimum range for the hybrid red tilapia, based on the known of the species $O$. mossambicus $\times O$. aureus: temperature $25.4 \pm 0.7^{\circ} \mathrm{C}$, salinity $34.8 \pm 0.5$, dissolved oxygen $5.1 \pm 0.2 \mathrm{mg} \mathrm{L}^{-1}$, total ammonia nitrogen $0.3 \pm$ $0.2 \mathrm{mg} \mathrm{L}^{-1}$, nitrite-nitrogen $0.2 \pm 0.3 \mathrm{mg} \mathrm{L}^{-1}$ and $\mathrm{pH} 7.8$ $\pm 0.2($ mean $\pm \mathrm{SE})$.

After 52 days, fish from each experimental unit were counted and individually weighted to assess the following performance metrics: weight gain $(\%)=$ [(final mean weight - initial mean weight $) \times 100 /$ initial mean weight $]$; feed intake $(\mathrm{FI})=[($ total food consumed per tank for the duration of the experiment / number of fish per tank]; feed conversion ratio $(\mathrm{FCR})=($ total amount of feed consumed / final body weight gain); specific growth rate $(\mathrm{SGR})=(\ln$ final weight $-\ln$ initial weight $) /$ time $($ days $) \times 100$; protein efficiency ratio $(\mathrm{PER})=\mathrm{g}$ body weight increase, wet weight $/ \mathrm{g}$ protein ingested; thermal growth coefficient $(\mathrm{TGC})=[($ final weight $^{1 / 3}$ - initial weight $\left.\left.{ }^{1 / 3}\right) /\left(\mathrm{T}^{\circ} \mathrm{C} \times \mathrm{D}_{\text {days }}\right)\right] \times 1000$; condition factor $(\mathrm{CF})=$ weight $/$ length ${ }^{3}$.

Three fish per tank were randomly collected and euthanized by ice-cold water. Firstly, fish were measured, weighed and dissected. Total viscera masses and liver samples were weighed to calculate the viscero- 
Table 1. Dietary formulation $\left(\mathrm{g} \mathrm{kg}^{-1}\right)$ and proximate composition. a'Soybean meal $45-48 \%$ protein, Alimentos Integronaturales S.A. (COLPAC), Nuevo León, México, bPoultry meal 68\% protein, National Renderers Association, Missouri, USA, ${ }^{c}$ Fish meal 65\% protein. Scoular de México S. de R.L. de C.V., 'Industrializadora de Maíz S.A. de C.V., México, ${ }^{\mathrm{e} B e e f}$ tallow Grasas y Derivados SA de CV, Tijuana, Baja California, México, ${ }^{\mathrm{f} D S M}$ Nutritional Products México, S.A. de C.V., contains (cholecalciferol, menadione, thiamine, riboflavine, pyridoxine, cyanocobalamin, pantothenic acid, folic acid, choline chloride, copper, zinc oxide, iron, manganese oxide, potassium iodide, selenium, phosphorus, potassium, sodium, calcium, organic acids, taurine, silicates, silicon oxide, silicon dioxide, aluminum oxide), ${ }^{g} \mathrm{DSM}$ Nutritional Products México, S.A. de C.V. contains (350 mg L-ascorbic acid per gram), ${ }^{\mathrm{h}} \mathrm{DHA}$ Natur ADM Animal nutrition, Mexico contains (17.0\% DHA).

\begin{tabular}{|c|c|c|c|}
\hline Ingredient & $25.6 \% \mathrm{CP}$ & $30.8 \% \mathrm{CP}$ & $35.6 \% \mathrm{CP}$ \\
\hline Soybean meal $^{\mathrm{a}}$ & 47.6 & 65.4 & 82.6 \\
\hline Poultry by-product meal ${ }^{\mathrm{b}}$ & 180.8 & 217.8 & 252.3 \\
\hline Fish meal $^{\mathrm{c}}$ & 71.4 & 88.8 & 108.3 \\
\hline Corn meal ${ }^{\mathrm{d}}$ & 171.3 & 168.2 & 165.1 \\
\hline Beef tallowe & 44.7 & 37.4 & 28.5 \\
\hline Corn starch ${ }^{\mathrm{d}}$ & 397.3 & 337.0 & 279.4 \\
\hline Gelatin & 57.0 & 56.1 & 55.0 \\
\hline Rovimix $^{\mathrm{f}}$ & 19.0 & 18.7 & 18.3 \\
\hline Stay- $C^{g}$ & 3.8 & 3.7 & 3.7 \\
\hline DHA $^{\mathrm{h}}$ & 4.8 & 4.7 & 4.6 \\
\hline Sodium benzoate & 2.2 & 2.1 & 2.1 \\
\hline Tocopherol & 0.1 & 0.1 & 0.1 \\
\hline \multicolumn{4}{|c|}{ Proximate composition (\% dry matter basis) } \\
\hline Crute protein & 25.6 & 30.8 & 35.6 \\
\hline Crute fat & 7.9 & 9.4 & 8.5 \\
\hline Ash & 6.0 & 6.0 & 9.9 \\
\hline Dry matter & 98.6 & 99.2 & 97.5 \\
\hline Gross energy $\left(\mathrm{kJ} \mathrm{g}^{-1}\right)$ & 17.4 & 17.7 & 16.8 \\
\hline
\end{tabular}

somatic index $(\mathrm{VSI})=100 \times($ viscera weight $/$ whole body weight) and hepatosomatic index (HIS) $=100 \times$ (liver weight / whole body weight). Then the same three fish per treatment were used for whole-body proximate composition analysis (same procedures as those previously described for dietary proximate composition analyses).

For statistical analysis, data homogeneity was tested by the Shapiro Wilk test, and the homoscedasticity was tested by Levene's test, followed by an analysis of variance (one-way ANOVA). When significant differences were detected, a Newman-Keuls' test was done. Significance was determined based on $P<0.05$. Polynomial regression analyses were carried out to further investigate the relationship between analytically verified dietary protein levels and performance and morphometric parameters (weight gain, SGR, FCR, PER, Feed intake, TGC, HSI and VSI). Polynomial regression analyses were also chosen for resulting in stronger $\mathrm{R}^{2}$ than other regression analyses, including logarithmic, exponential, among others. All the statistical analyses were performed using the software Statistica 7.0.
The dietary protein levels tested did not affect the survival rate and growth performance across different treatments. Overall, juvenile hybrid red tilapia $(O$. mossambicus $\times$ O. aureus) demonstrated high production performance in all treatments (weight gain $=391$ $503 \%, \mathrm{FCR}=0.90-1.07$ and $\mathrm{SGR}=3.12-3.51 \%$ body weight $\mathrm{d}^{-1}$; Table 2).

Most production parameters were not statistically significant different (weight gain $P=0.789$; FCR $P=$ 0.582 ; SGR $P=0.604$; TGC $P=0.705$; CF $P=0.732$ ). Only fish fed the $30.8 \%$ CP diet exhibited significantly higher feed intake $(P<0.05)$ compared to those fed $25.6 \%$ CP (4.29 vs. $3.11 \%$ body weight $\mathrm{d}^{-1}$, respectively). (Fig. 1).

Although PER was not significantly affected by dietary protein level fish fed the $25.6 \% \mathrm{CP}$ diets demonstrated numerically higher values (4.34) than those fed the other dietary treatments (3.06 and 3.35). The VSI was significantly reduced in $25.6 \% \mathrm{CP}$ group (3.1) compared to $30.8 \% \mathrm{CP}$ (7.9) and $35.6 \% \mathrm{CP}$ groups (8.2), and no difference was observed for HSI (2.6-3.3). 
Table 2. Production performance by dietary treatment. Values represent least-square means and standard error (SE) values and $P$-values resulting from one-way ANOVA tests are also provided; means with common letter labels are not significantly different $(P>0.05)$. FCR: feed conversion ratio, SGR: specific growth rate, FI: feed intake, PER: protein efficiency ratio, TGC: thermal growth coefficient, CF: condition factor, HSI: hepatosomatic index, VSI: viscerosomatic index.

\begin{tabular}{lcccc}
\hline Production variable & $25.6 \% \mathrm{CP}$ & $30.8 \% \mathrm{CP}$ & $35.6 \% \mathrm{CP}$ & $P$-value \\
\hline Initial individual weight $(\mathrm{g})$ & $4.4 \pm 0.4$ & $3.8 \pm 0.1$ & $4.3 \pm 0.7$ & 0.309 \\
Final individual weight $(\mathrm{g})$ & $21.6 \pm 2.6$ & $22.7 \pm 2.1$ & $23.6 \pm 5.4$ & 0.795 \\
Weight gain $(\%)$ & $391 \pm 31$ & $503 \pm 64$ & $472 \pm 26$ & 0.789 \\
FCR & $0.90 \pm 0.02$ & $1.07 \pm 0.03$ & $0.93 \pm 0.19$ & 0.582 \\
SGR $\left(\%\right.$ body weight $\left.^{-1}\right)$ & $3.12 \pm 0.12$ & $3.51 \pm 0.21$ & $3.31 \pm 0.76$ & 0.604 \\
FI $\left(\mathrm{g} \mathrm{fish}^{-1}\right)$ & $3.11 \pm 0.14^{\mathrm{b}}$ & $4.29 \pm 0.31^{\mathrm{a}}$ & $3.27 \pm 0.25^{\mathrm{ab}}$ & 0.027 \\
Survival (\%) & 100 & 100 & 100 & \\
PER & $4.34 \pm 0.09$ & $3.06 \pm 0.26$ & $3.35 \pm 0.79$ & 0.226 \\
TGC & $1.50 \pm 0.05$ & $1.67 \pm 0.07$ & $1.61 \pm 0.23$ & 0.705 \\
CF & $0.19 \pm 0.06$ & $0.26 \pm 0.08$ & $0.20 \pm 0.04$ & 0.732 \\
HSI & $3.3 \pm 0.6$ & $2.6 \pm 1.7$ & $3.2 \pm 0.4$ & 0.315 \\
VSI & $3.1 \pm 0.7^{\mathrm{b}}$ & $7.9 \pm 1.7^{\mathrm{a}}$ & $8.2 \pm 0.2^{\mathrm{a}}$ & 0.002 \\
\hline
\end{tabular}

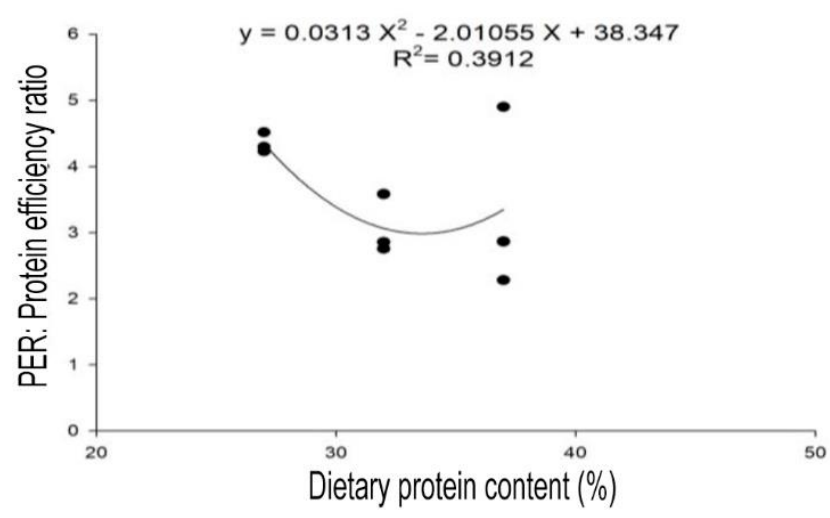

Figure 1. Polynomial regression analyses between dietary protein content and protein efficiency ratio (PER) and feed intake (FI).

The polynomial regression analyses demonstrated a stronger relationship between dietary protein content and VSI and FI ( $R^{2}=0.87$ and 0.70 , respectively) than the rest of the parameters analyzed $\left(\mathrm{R}^{2}=0.08-0.39\right.$, Table 3). A positive correlation was noticed for PER and HSI, whereas the other parameters displayed a negative correlation. Regarding the relative wholebody composition (Table 4), the dietary protein significantly affected all parameters, except lipid content. The whole-body dry matter was reduced in the $25.6 \% \mathrm{CP}$ group $\left(980 \mathrm{~g} \mathrm{~kg}^{-1}\right)$ compared to the 30.8 and $35.6 \% \mathrm{CP}$ groups (985 and $987 \mathrm{~g} \mathrm{~kg}^{-1}$, respectively). Decreased protein content $\left(563 \mathrm{~g} \mathrm{~kg}^{-1}\right)$ and high ash content $\left(171 \mathrm{~g} \mathrm{~kg}^{-1}\right)$ in the whole-body of fish fed the $30.8 \%$ CP diets was revealed compared to those fed the other dietary treatments (586-590 $\mathrm{g} \mathrm{kg}^{-1}$ and $139-136 \mathrm{~g}$ $\mathrm{kg}^{-1}$, respectively). Collectively, these findings suggest the optimum dietary protein content for hybrid red tilapia under the experimental conditions was $25.6 \%$.

The tilapia has a low trophic level, and consequently, it demands reduced dietary protein when compared with other higher trophic level commercial aquaculture species (e.g., 30-40\% CP vs. 40-55\% CP). Protein is an essential nutrient for growth and other numerous physiological processes; in general, fish has an elevated dietary protein demand compared to terrestrial animals (Chou et al., 2001; Ai et al., 2004; Li et al., 2008). The knowledge on optimum dietary protein demand is paramount in aquaculture for the growth maximization and performance, productivity optimization, and production costs reduction (Salhi et al., 2004). In our study, juveniles of hybrid red tilapia (O. mossambicus $\times$ O. aureus) exhibited higher growth and production performance than those reported by $\mathrm{Li}$ et al. (2008).

On the other hand, Barreto-Curiel et al. (2015) reported higher weight gain and TGC compared to the present findings. In that study, the authors investigated the hybrid red tilapia performance $(25.00 \pm 0.06 \mathrm{~g}$, initial weight) reared in fresh $v s$. seawater for 90 days fed diets containing $40 \% \mathrm{CP}$ and $8.5 \%$ crude fat. These contradictory differences are difficult to explain, considering that fish from one of our treatments were fed similar protein content to those reported by BarretoCuriel (37 vs. 40\% CP). Those differences could be a result of many factors: such as fish size, genetics, length of the feeding trial and culture system, among others.

The protein efficiency ratio (PER value) reflects the dietary protein quality to growth performance. As such, the higher PER value indicates greater efficiency on 
Table 3. Regression analyses of dietary protein content and production performance parameters, the type of regression analyses used was polynomial. SGR: specific growth rate, FCR: feed conversion ratio, PER: protein efficiency ratio, FI: feed intake, TGC: thermal growth coefficient, HSI: hepatosomatic index, VSI: viscerosomatic index.

\begin{tabular}{llc}
\hline & \multicolumn{1}{c}{ Equation } & $\mathrm{R}^{2}$ \\
\hline Weight gain $(\%)$ & $\mathrm{y}=-0.026 \mathrm{x}^{2}+1.8743 \mathrm{x}-14.496$ & 0.076 \\
SGR & $\mathrm{y}=-0.012 \mathrm{x}^{2}+0.7856 \mathrm{x}-9.3732$ & 0.154 \\
FCR & $\mathrm{y}=-0.0064 \mathrm{x}^{2}+0.4131 \mathrm{x}-5.582$ & 0.164 \\
PER & $\mathrm{y}=0.0313 \mathrm{x}^{2}-2.1055 \mathrm{x}+38.347$ & 0.391 \\
FI & $\mathrm{y}=-0.044 \mathrm{x}^{2}+2.8351 \mathrm{x}-41.325$ & 0.700 \\
TGC & $\mathrm{y}=-0.0044 \mathrm{x}^{2}+0.2944 \mathrm{x}-3.23$ & 0.110 \\
HSI & $\mathrm{y}=0.0256 \mathrm{x}^{2}-1.6539 \mathrm{x}+29.338$ & 0.319 \\
VSI & $\mathrm{y}=-0.0888 \mathrm{x}^{2}+6.1942 \mathrm{x}-99.37$ & 0.871 \\
\hline
\end{tabular}

Table 4. Whole-body composition $\left(\mathrm{g} \mathrm{kg}^{-1}\right)$ of juvenile hybrid red tilapia Oreochromis mossambicus $\times$ O. aureus fed diets with increasing dietary protein content. Values represent least-square means and standard error (SE) values and $P$-values resulting from one-way ANOVA tests are also provided; means with common letter labels are not significantly different $(P$ $>0.05)$.

\begin{tabular}{llllc}
\hline & $25.6 \% \mathrm{CP}$ & $30.8 \% \mathrm{CP}$ & $35.6 \% \mathrm{CP}$ & $P$-value \\
\hline Dry matter & $980 \pm 00^{\mathrm{b}}$ & $985 \pm 00^{\mathrm{a}}$ & $987 \pm 00^{\mathrm{a}}$ & 0.002 \\
Protein & $586 \pm 60^{\mathrm{a}}$ & $563 \pm 20^{\mathrm{b}}$ & $590 \pm 11^{\mathrm{a}}$ & 0.005 \\
Lipid & $265 \pm 02$ & $270 \pm 11$ & $270 \pm 00$ & 0.565 \\
Ash & $139 \pm 00^{\mathrm{b}}$ & $171 \pm 20^{\mathrm{a}}$ & $136 \pm 04^{\mathrm{b}}$ & 0.026 \\
\hline
\end{tabular}

protein utilization by fish, while lower PER value shows a decrease in protein utilization, probably as a result of low protein digestibility and absorption, or that protein is being used as an energy source (Clark et al., 1990). The protein efficiency is affected by many factors, mainly fish size, age and protein source (AlHafedh, 1999). Carvalho et al. (2017) reported a reduction of PER value with an increase of dietary protein level increasing ammonia excretion. In the present study, the PER values were not statistically different among dietary treatments. However, the polynomial regression analysis indicated a negative relationship between PER value and dietary protein content, where fish fed the 25.6 and $30.8 \%$ CP diets exhibited the highest and lowest PER value numerically, respectively, and in accordance to the literature (Wing-Keong \& Rosdiana, 2007; Carvalho et al., 2017). So, considering the polynomial regression analysis, it can be stated that $25.6 \% \mathrm{CP}$ can be considered as the optimum dietary protein content. Also, no signs of ammonia excretion increased were observed regarding the water quality monitoring throughout the feeding trial; which demonstrates that fish were satisfactorily utilizing the dietary protein.

The salinity content appears to no interfere with the PER values in hybrid red tilapia, as no statistical difference was reported in PER values for juvenile (25 g) reared in fresh (2.08) and seawater (1.97) (BarretoCuriel et al., 2015). Freshwater species when exposited to an increasing water salinity use the osmoregulation process to keep the homeostasis of fluids due to the size of the intestine (Verdegem et al., 1997; Chourasia et al., 2018).

In the present study, feed intake was affected by dietary treatments with fish fed the $30.8 \% \mathrm{CP}$ diet exhibiting significantly higher feed intake than those fed the $25.6 \%$ CP diet. Generally, energy is considered the primary driver in feed intake; however, many other factors (e.g., availability of key nutrients, palatability and attractants, among others) should be considered as well (De la Higuera, 2001). Nevertheless, the feed intake should be taken with care, since it is difficult to establish a high accuracy due to the feed stability and feed recovery from the experimental tanks. Moreover, since the gross energy of the dietary treatments was equivalent, it can be suggested that other factors including availability of nutrients (e.g., higher dietary lipid content in the $30.8 \% \mathrm{CP}$ diet compared to the 25.6 and $35.6 \% \mathrm{CP}$ diets) might have influenced this outcome. The higher visceral somatic index in fish fed diets containing elevated protein levels could be related to the increase in feed intake and the mobilization of fat (Duarte et al., 2019). 
Our results indicate that juveniles of hybrid red tilapia (O. mossambicus $\times$ O. aureus) accepted all dietary treatments. Growth performance can be increased with higher dietary protein content (30.8 and $35.6 \% \mathrm{CP}$ ) although not as efficient as diets containing 25.6\% CP. Regression analyses based on PER value suggested that the optimum dietary protein content for juvenile hybrid red tilapia was $25.6 \%$ under the experimental conditions.

\section{ACKNOWLEDGMENTS}

The authors sincerely thank Aurora Tinajero-Chavez, Desiree Barba-Carballo, Griselda Pares and Christian Cortez for their assistance with data collection and analysis.

\section{REFERENCES}

Ai, Q., Mai, K., Li, H., Zhang, C., Zhang, L., Duan, Q. \& Liufu, Z. 2004. Effects of dietary protein to energy ratios on growth and body composition of juvenile Japanese seabass, Lateolabrax japonicus. Aquaculture, 230: 507-516.

Al-Hafedh, Y.S. 1999. Effects of dietary protein on growth and body composition of Nile tilapia, Oreochromis niloticus. Aquaculture Research, 30: 385-393.

Association of Official Analytical Chemists (AOAC). 1995. Official Methods of Analysis of AOAC International. AOAC International, Arlington.

Barreto-Curiel, F., Durazo, F.E. \& Viana, M.T. 2015. Growth, ammonium excretion, and oxygen consumption of hybrid red tilapia (Oreochromis mossambicus $\times$ Oreochromis aureus) grown in seawater and freshwater. Ciencias Marinas, 41(3): 247-254.

Botello-Leon, A., Viana, M.T., Tellez-Giron, E., PullesAriza, E., Cisneros-Lopez, M., Solano-Silveira, G. \& Savon, L. 2011. Fish meal substitution by proteinsugar cane in diets for weight gain in red tilapia. Agrociencia, 45(1): 23-31.

Brol, J., Pinho, S.M., Sgnaulin, T., Pereira, K.D.R., Thomas, M.C., Mello, G.L. \& Emerenciano, M.G.C. 2017. Tecnologia de bioflocos (BFT) no desempenho zootécnico de tilápias: efeito da linhagem e densidades de estocagem. Archivos de Zootecnia, 66(254): 229235.

Carvalho, M.A.G.D., Fernandes, L.F.L. \& Gomes, L.D.C. 2017. Digestibility, protein retention rate and ammonia excretion in juvenile fat snook (Centropomus parallelus) fed with different protein levels. Ciência Rural, 47(7): e20160369.
Chou, R.L., Su, M.S. \& Chen, H.Y. 2001. Optimal dietary protein and lipid levels for juvenile cobia (Rachycentron canadum). Aquaculture, 193(1-2): 81-89.

Chourasia, T.K., D'Cotta, H., Baroiller, J.F., Slosman, T. \& Cnaani, A. 2018. Effects of the acclimation to high salinity on intestinal ion and peptide transporters in two tilapia species that differ in their salinity tolerance. Comparative Biochemistry and Physiology A, Molecular \& Integrative Physiology, 228: 16-23.

Clark, A.E., Watanabe, W.O., Olla, B.L. \& Wicklund, R.I. 1990. Growth, feed conversion, and protein utilization of Florida red tilapia fed isocaloric diets with different protein levels in seawater pools. Aquaculture, 88(1): $75-85$.

De la Higuera, M. 2001. Effects of nutritional factors and feed characteristics on feed intake. In: Houlihan, D., Boujard, T. \& Jobling, M. (Eds.). Food intake in fish. Willey-Blackwell, Hoboken, pp. 250-268.

Duarte, G., Lucena, J.E., Almeida, O.C.D. \& Bicudo, A.J. 2019. Growth and body composition of juvenile curimatã-pacu (Prochilodus argenteus) fed diets with different protein: lipid ratios. Latin American Journal of Aquatic Research, 47(1): 114-121.

El-Saidy, DM. \& Gaber, M. 2005. Effect of dietary protein levels and feeding rates on growth performance, production traits, and body composition of Nile tilapia, Oreochromis niloticus cultured in concrete tanks. Aquaculture Research, 36(2): 163-171.

Food and Agriculture Organization (FAO). 2016. The state of world fisheries and aquaculture: contributing to food security and nutrition for all. FAO, Rome.

He, Y.F., Wang, L.M., Zhu, W.B., Dong, Z.J. \& Liu, N. 2017. Effects of salinity on cold tolerance of Malaysian red tilapia. Aquaculture International, 25(2): 777-792.

Kaushik, S.J. \& Seiliez, I. 2010. Protein and amino acid nutrition and metabolism in fish: current knowledge and future needs. Aquaculture Research, 41(3): 322332.

Li, P., Mai, K., Trushenski, J. \& Wu, G. 2008. New developments in fish amino acid nutrition: towards functional and environmentally oriented aquafeeds. Amino Acids, 37(1): 43-53.

Liu, W., Wen, H., \& Luo, Z. 2017. Effect of dietary protein levels and feeding rates on the growth and health status of juvenile genetically improved farmed tilapia (Oreochromis niloticus). Aquaculture International, 26: 153-167.

Ma, F., Li, X., Li, B. \& Leng, X. 2015. Effects of extruded and pelleted diets with different protein levels on growth and nutrient retention of tilapia, Oreochromis 
niloticus $\times O$. aureus. Aquaculture International, 23(6): 1341-1356.

Msangi, S., Kobayashi, M., Batka, M., Vannuccini, S., Dey, M.M. \& Anderson, J.L. 2013. Fish to 2030. Prospects for fisheries and aquaculture. World Bank Report, 83177-GLB: 80 pp.

Nakphet, S., Ritchie, R.J. \& Kiriratnikom, S. 2017. Aquatic plants for bioremediation in red hybrid tilapia (Oreochromis niloticus $\times$ Oreochromis mossambicus) recirculating aquaculture. Aquaculture International, 25(2): 619-633.

Salhi, M., Bessonart, M., Chediak, G., Bellagamba, M. \& Carnevia, D. 2004. Growth, feed utilization, and body composition of black catfish, Rhamdia quelen, fry fed diets containing different protein and energy levels. Aquaculture, 231(1-4): 435-444.

Received: 4 March 2019; Accepted: 1 July 2019
Verdegem, M.C.J., Hilbrands, A.D. \& Boon, J.H. 1997. Influence of salinity and dietary composition on blood parameter values of hybrid red tilapia, Oreochromis niloticus (Linnaeus) $\times$ O. mossambicus (Peters). Aquaculture Research, 28(6): 453-459.

Watanabe, W.O., Losordo, T.M., Fitzsimmons, K. \& Hanley, F. 2002. Tilapia production systems in the Americas: technological advances, trends, and challenges. Reviews in Fisheries Science, 10(3-4): 465-498.

Wing-Keong, N.G. \& Rosdiana, H. 2007. Performance of genetically improved Nile tilapia compared with red hybrid tilapia fed diets containing two protein levels. Aquaculture Research, 38(9): 965-972. 